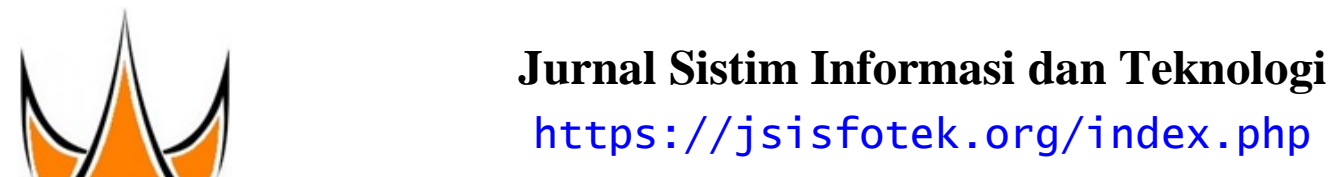

\title{
Sistem Pakar Metode Forward Chaining untuk Mengukur Keparahan Penyakit Gigi dan Mulut
}

\author{
Ilham Roni Yansyah $^{1 凶}$, Sumijan $^{2}$ \\ ${ }^{1,2}$ Universitas Putra Indonesia YPTK Padang \\ ronyexcol@gmai1.com
}

\begin{abstract}
Teeth and mouth are parts of the body that cannot be separated, where the teeth are in the oral cavity so that if there is interference with the teeth it will affect the mouth. Knowledge to recognize dental and oral diseases from an early age is very much needed to be able to maintain healthy teeth and mouth. Lack of knowledge about these oral and dental diseases will result in severe damage to teeth and mouth. This study aims to measure the severity of oral disease and provide a diagnosis of oral and dental disease so that later it can be used as a reference for consultation with a doctor. The method used in this research is Forward Chaining to represent the rules of 27 symptom facts and 8 diseases described by experts. The results of testing for this method are as many as 10 patient data were diagnosed to get the same result as the doctor's analysis so that the accuracy rate is $80 \%$. The expert system designed with the Codeigniter Framework can provide insight by being able to identify the disease suffered by patients and measure the severity of the oral and dental disease suffered.
\end{abstract}

Keywords: Teeth and Mouth, Disease severity, Knowledge, Forward Chaining, Framework Codeigniter.

\begin{abstract}
Abstrak
Gigi dan mulut merupakan bagian dari organ tubuh yang tidak dapat dipisah, dimana gigi berada didalam rongga mulut sehinggah jika terjadi gangguan pada gigi akan berdampak terhadap mulut. Pengetahuan untuk mengenali penyakit gigi dan mulut sejak dini sangat dibutuhkan untuk dapat menjaga kesehatan gigi dan mulut.Kurangnya pengetahuan mengenai penyakit gigi dan mulut ini nantinya berakibat kerusakan yang parah terhadap gigi dan mulut. Penelitian ini bertujuan untuk mengukur keparahan penyakit gigi dan mulut serta memberikan diagnosis terhadap penyakit gigi dan mulut yang diderita sehingga nantinya dapat menjadi acuan untuk konsultasi ke dokter. Metode yang digunakan dalam penelitian ini yaitu Forward Chaining untuk merepresentasikan Rule atau kaidah dari 27 fakta gejala dan 8 penyakit yang dipaparkan oleh pakar. Hasil dari pengujian terhadap metode ini adalah sebanyak 10 data pasien yang didiagnosa mendapatkan hasil 8 sama dengan analisis dokter sehingga tingkat akurasinya sebesar $80 \%$. Dengan demikian sistem pakar yang dirancang dengan Framework Codeigniter ini dapat telah mampu memberikan pengertahuan dengan dapat mengidentifikasi penyakit yang diderita pasien serta mengukur keparahan penyakit gigi dan mulut yang diderita.
\end{abstract}

Kata kunci: Gigi dan Mulut, Keparahan penyakit, Pengetahuan, Forward Chaining, Framework Codeigniter.

(C) 2021 JSisfotek

\section{Pendahuluan}

Kesehatan merupakan salah satu kebutuhan dasar manusia disamping pangan, pemukiman dan pendidikan, karena hanya dalam keadaan sehat manusia dapat hidup, tumbuh dan berkarya lebih baik. Banyak masyarakat yang kurang memperhatikan kesehatan, terutama pada kesehatan gigi dan mulut karena penyakit gigi dan mulut dapat menyerang siapa saja dan kapan saja [1]. Terdapat banyak faktor yang menyebabkan jarangnya seseorang melakukan pemeriksaan dan konsultasi ke dokter gigi, diantaranya adalah kurangnya rasa perhatian atau kesadaran akan kesehatan gigi dan mulut, mahalnya biaya yang harus dikeluarkan untuk konsultasi, panjangnya antrian yang menyebabkan pasien kurang betah dalam menunggu [2].
Untuk mengatasi permasalahan tersebut maka dilakukanlah penelitian sehingga diperlukan sebuah aplikasi sistem pakar untuk melakukan diagnosa sejak dini mengenai tingkat keparahan penyakit gigi dan mulut yang diderita sehingga nantinya didapatkan solusi penanganannya sebelum dibawa ke dokter. Pada penelitian ini penulis mencoba membuat aplikasi web dengan menggunkan metode Inferensi Forward Chaining. Sistem ini dibangun menggunakan Framewoork Codeigniter. Sistem pakar adalah sistem komputer yang didasarkan pada pengetahuan terintegrasi dalam sistem informasi dasar yang ada, sehingga memiliki kemampuan untuk menyelesaikan masalah di bidang tertentu secara cerdas dan efektif, sebagaimana layaknya seorang pakar [3]. Sistem Pakar harus dilengkapi sebuah metode yang dapat memberikan atau menghasilkan nilai output atas fakta-

Diterima: 16-10-2020 | Revisi: 31-10-2020 | Diterbitkan: 30-06-2021 | DOI: 10.37034/jsisfotek.v3i2.42 
fakta yang diderita pasien. Metode yang dapat digunakan salah satunya metode Forward Chaining. Forward Chaining merupakan salah satu teknik penelusuran pengetahuan yang dimulai dari keadaan atau fakta untuk kemudian menghasilkan sebuah kesimpulan (conclusion) berdasarkan fakta tersebut. Forward Chaining dapat pula dikatakan sebagai sebuah teknik inferense yang dimulai dari sejumlah fakta yang diketahui untuk mendapatkan jawaban atau solusi yang dicari [4].

Framework CodeIgniter merupakan sebuah aplikasi terbuka atau open source yang berfondasi dari framework PHP dengan model MVC atau juga biasa disebut Model View Controller yang digunakan untuk membangun suatu website dinamik dengan menggunakan kode PHP [5]. Beberapa penelitian menggunakan metode Forward Chaining adalah penelitian mendiagnosa penyakit osteoporosis dengan hasil metode telah berfungsi dengan cukup baik (akurat) sehingga dapat digunakan untuk membantu mendiagnosa penyakit osteoporosis yang diderita oleh pasien dengan persentase keberhasilan 83,3\% [6].

Penelitian lainnya yang menggunakan Forward Chaining yaitu untuk konsultasi prilaku siswa diamana disini didapatkan keberhasilan dan metode berjalan baik dengan persentase keberhasilan 89,60\% [7] Sedangkan penelitian dalam mendiagnosa hama dan penyakit pada bunga, berdasarkan hasil pengujian yang telah dilakukan pada sistem pakar sebanyak 21 kali,akurasi yang didapat sebanyak $90.48 \%$ sesuai dengan jawaban yang didapatkan dari pakar [8]. Hasil pengujian sistem pakar diagnosa penyakit tanaman padi menemukan pada 15 kasus berbeda dilapangan selanjutnya membandingkan hasil dari pakar terdapat kesesuaian sebesar $100 \%$ terhadap diagnosa penyakit tanaman padi [9]. Pada sistem pakar diagnosa dosis obat pada anak memiliki presentase $48,8 \%$. Selain itu kesesuaian program ini juga mendapatkan prosentase yang besar juga [10].

\section{Metodologi Penelitian}

Metodologi penelitian yang digunakan dalam penelitian ini terdiri dari beberapa langkah-langkah dan kerangka dari penelitian ini dapat dilihat pada Gambar 1.

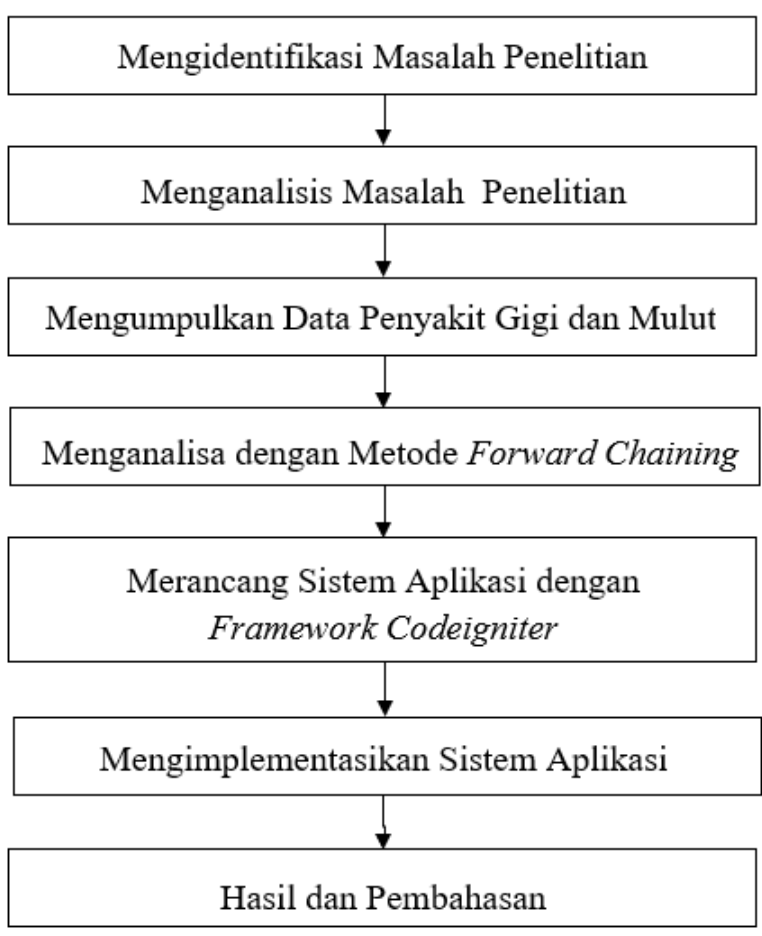

Gambar 1. Kerangka Kerja Penelitian

Penelitian ini dilakukan secara urut sesuai dengan kerangka pada Gambar 1 dan berikut adalah pemaparan mengenai kerangka tersebut:

2.1 Mengidentifikasi Masalah Penelitian

Pada tahapan ini langkah awal untuk mempersiapkan penelitian adalah identifikasi masalah serta mencari sumber literatur.

\subsection{Menganalisis Masalah Penelitian}

Pada tahapan menganalisis masalah adalah untuk memahami masalah yang dipilih ruang lingkup dan batasan masalahnya.

\subsection{Mengumpulkan Data Penyakit Gigi dan Mulut}

Pada tahap mengumpulkan data dilakukan untuk dapat memperoleh informasi data-data yang dibutuhkan dalam rangka mencapai tujuan penelitian. Pada metode penelitian ini peneliti menggunakan beberapa metode penelitian dalam pengumpulan data, yaitu field research dan teknik kalkulasi.

\subsection{Menganalisa Dengan Metode Forward Chaining}

Pada tahapan ini agar permasalahan penelitian ini dapat dianalisa maka digunakan metode Forward Chaining, dengan harapan dapat memberikan solusi dan penangganan terhadap penyakit gigi dan mulut.

\subsection{Merancang Sistem Aplikasi Dengan Framework Codeigniter}

Hasil dari tahapan ini nantinya menghasilkan sebuah sistem yang dapat digunakan untuk memproses analisa penelitian secara terkomputerisasi.

2.6 Mengimplementasikan Sistem Aplikasi

Jurnal Sistim Informasi dan Teknologi Vol. 3 No. 2 (2021) 41-47 
Pada tahapan ini implementasi ini dilakukan untuk user sebagai masukan ke dalam sistem. Proses membandingkan hasil yang didapatkan dengan analisa perhitungan ini terdiri dari beberapa tahapan, pada secara manual dengan sistem aplikasi yang dibuat.

Gambar 2.

\subsection{Hasil dan Pembahasan}

Tahap ini akan diuraikan hasil dari pengolahan dan pengujian data yang telah dilakukan dengan menggunakan metode Forward Chaining. Hasil dari identifikasi tersebut akan dibandingkan dengan datadata riil yang ada untuk melihat tingkat persentase (\%) keakuratannya.

\section{Hasil dan Pembahasan}

Pada hasil dan pembahasan terdapat beberapa kegiatankegiatan. Pembagian kegiatan tersebut diuraikan dalam tahapan-tahapan pada sub bagian berikut.

\subsection{Analisis Data}

Data yang digunakan dalam penelitian ini merupakan data yang didapatkan dari seorang pakar melalui wawancara dengan pakar yaitu drg. Wahyudi. Data ini diperoleh secara formal oleh peneliti yaitu dengan melakukan kegiatan penelitian bersama pakar untuk memperoleh data.

Berikut adalah list beberapa data data identifikasi pnyakit gigi dan mulut yang dijadikan data uji coba untuk diimplementasikan dengan metode Forward Chaining dapat dilihat pada Tabel 1.

Tabel 1. Data Identifikasi Penyakit Gigi Dan Mulut

\begin{tabular}{|c|c|c|}
\hline Pasien & Gejala & Penyakit \\
\hline Pasien 1 & $\begin{array}{l}\text { - Gusi yang nyeri saat disentuh. } \\
\text { - Nanah antara gigi dan gusi. } \\
\text { - Gigi goyang. } \\
\text { - Penumpukan plak dan karang gigi. } \\
\text { - Pendarahan dari gusi saat ditekan } \\
\text { sedikit. } \\
\text { - Mulut berbau. } \\
\text { - Luka yang seperti kawah (ulkus) di } \\
\text { antara gigi dan gusi. }\end{array}$ & Periodentitis \\
\hline Pasien 2 & $\begin{array}{l}\text { - Rasa tidak nyaman pada mulut. } \\
\text { - Nyeri saat makan atau menelan. } \\
\text { - Mulut berbau. } \\
\text { - Demam dan kelelahan. }\end{array}$ & Pulpitis \\
\hline Pasien 3 & $\begin{array}{l}\text { - Sakit kepala berkepanjangan. } \\
\text {-Pembengkakan di sekitar rahang. } \\
\text { - Nyeri saat makan atau menelan. } \\
\text { - Gusi merah atau bengkak. } \\
\text { - Pembengkakan kelenjar limfa di } \\
\text { sekitar kepala, leher atau rahang }\end{array}$ & Impaksi Gigi \\
\hline Pasien 4 & $\begin{array}{l}\text { - Adanya inflamasi atau peradangan } \\
\text { di sekitar gigi yang mengenai } \\
\text { jaringan lunak pada gigi. } \\
\text { - Gusi kendur, bergeser atau lepas. } \\
\text { - Pendarahan dari gusi saat ditekan } \\
\text { sedikit. } \\
\text { - Perubahan warna gusi. } \\
\text { - Mulut berbau. } \\
\text { - Nyeri saat makan atau menelan. }\end{array}$ & Gingivitis \\
\hline
\end{tabular}

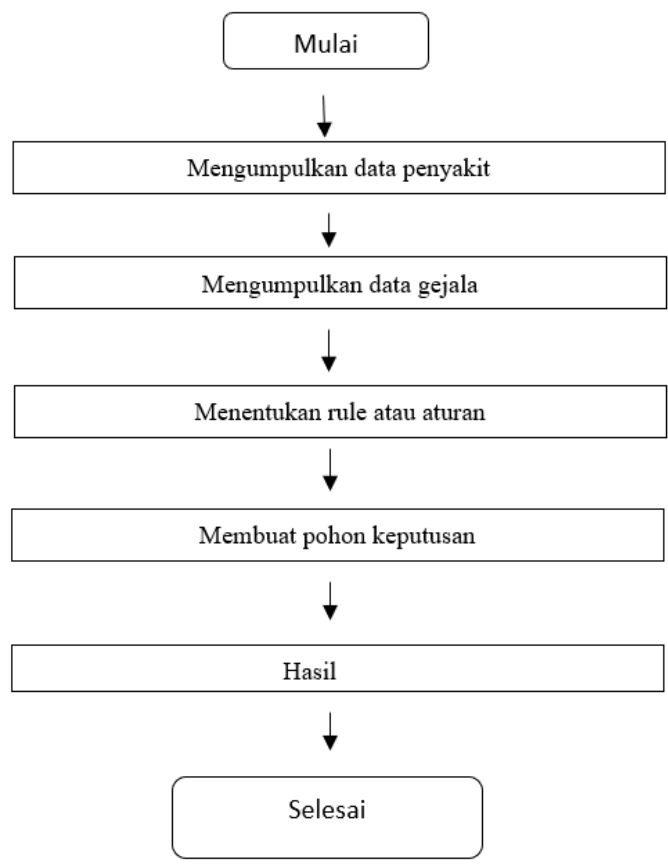

Gambar 2. Flowchart Proses Metode Forward Chaining

Berdasarkan flowchart algoritma Forward Chaining pada Gambar 2, maka dapat dijelaskan alir pengerjaan sistem dengan Forward Chaining sebagai berikut:

3.2.1. Mengumpulkan Data Penyakit

Masalah yang dibahas dalam penelitian ini adalah mengenai jenis penyakit gigi dan mulut yang umum diderita oleh manusia. Jenis-jenis penyakit gigi dan mulut dapat dilihat pada Tabel 2.

Tabel 2. Data Penyakit Gigi Dan Mulut

\begin{tabular}{|cc}
\multicolumn{1}{c}{ Kode Penyakit } & Jenis Penyakit \\
\hline T1 & Gingivitis \\
T2 & Karies gigi \\
T3 & Trench Mouth \\
T4 & Pulpitis \\
T5 & Nekrosis Pulpa \\
T6 & Periodentitis \\
T7 & Impaksi Gigi \\
T8 & Glositis \\
\hline
\end{tabular}

Berdasarkan Tabel 2 terdapat 8 jenis penyakit gigi dan mulut dengan kode T1-T8.

\subsubsection{Mengumpulkan Data Gejala}

Penyakit gigi dan mulut ini memiliki 27 gejala yang menandai penyakit tersebut, seperti pada Tabel 3.

\section{2. Analisa Sistem}

Perhitungan Sistem Pakar ini menggunakan metode Forward Chaining yaitu dimulai dari sekumpulan fakta-fakta tentang suatu gejala yang diberikan oleh 
Tabel 3. Data Gejala Penyakit Gigi Dan Mulut

\begin{tabular}{cl}
\hline Kode Gejala & \multicolumn{1}{c}{ Jenis Gejala } \\
\hline Q1 & Mulut berbau. \\
Q2 & Nyeri saat makan atau menelan. \\
Q3 & Pendarahan dari gusi saat ditekan sedikit. \\
Q4 & Perubahan warna gusi. \\
Q5 & Adanya inflamasi atau peradangan di sekitar ggigi \\
& yang mengenai jaringan lunak pada gigi. \\
Q6 & Gusi kendor, bergeser atau lepas. \\
Q7 & Gigi yang menjadi lebih sensitif. \\
Q8 & Ada noda coklat, hitam atau putih pada \\
& permukaan gigi. \\
Q9 & Rasa tidak nyaman pada mulut. \\
Q10 & Sakit gigi muncul secara tiba-tiba tanpa sebab \\
& yang jelas. \\
Q11 & Luka seperti kawah diantara gigi dan gusi. \\
Q12 & Demam dan kelelahan. \\
Q13 & Pembengkakan kelenjar limfa di sekitar kepala, \\
& leher atau rahang. \\
Q14 & Rasa sakit yang menusuk tajam dan intens. \\
Q15 & Nyeri pada gigi berlansung beberapa jam. \\
Q16 & Nyeri tambah parah di malam hari. \\
Q17 & Nyeri muncul atau bertambah pada saat posisi \\
& tubuh tertentu (merunduk). \\
Q18 & Gusi nyeri saat disentuh. \\
Q19 & Ada nanah antara gigi dan gusi. \\
Q20 & Gigi goyang. \\
Q21 & Penumpukan plak dan karang gigi. \\
Q22 & Sakit kepala berkepanjangan. \\
Q23 & Pembengkakan di rahang. \\
Q24 & Gusi merah atau membengkak. \\
Q25 & Rasa sakit pada area lidah. \\
Q26 & Bengkak pada lidah. \\
Q27 & Perubahan warna lidah jadi pucat atau merah \\
& terang. \\
\hline
\end{tabular}

Tabel 3 menjelaskan gejala yang digunakan pada penelitian ini sebanyak 27 gejala dengan pengkodean dari Q1-Q27.

\subsubsection{Menentukan Rule Atau Aturan}

Setelah diketahui data yang akan diolah, langkah selanjutnya adalah dibuat suatu hubungan antara gejala dengan penyakit yang didapatkan dari wawancara dengan pakar yang terlihat pada Tabel 4.

Tabel 4. Rule Atau aturan

\begin{tabular}{cl}
\hline No & \multicolumn{1}{c}{ Rule } \\
\hline 1 & IF Q1 AND Q2 AND Q3 AND Q4 AND Q5 AND Q6 THEN \\
& T1 \\
2 & IF Q1 AND Q2 AND Q7 AND Q8 AND Q9 AND Q10 THEN \\
& T2 \\
3 & IF Q1 AND Q2 AND Q3 AND Q4 AND Q6 AND Q9 AND \\
& Q11 AND Q12 AND Q13 THEN T3 \\
4 & IF Q1 AND Q2 AND Q9 AND Q12 THEN T4 \\
6 & IF Q14 AND Q15 AND Q16 AND Q17 THEN T5 \\
& IF Q1 AND Q3 AND Q11 AND Q18 AND Q19 AND Q20 \\
7 & AND Q21 THEN T6 \\
8 & IF Q2 AND Q13 AND Q22 AND Q23 AND Q24 THEN T7 \\
\end{tabular}

$\mathrm{R}$

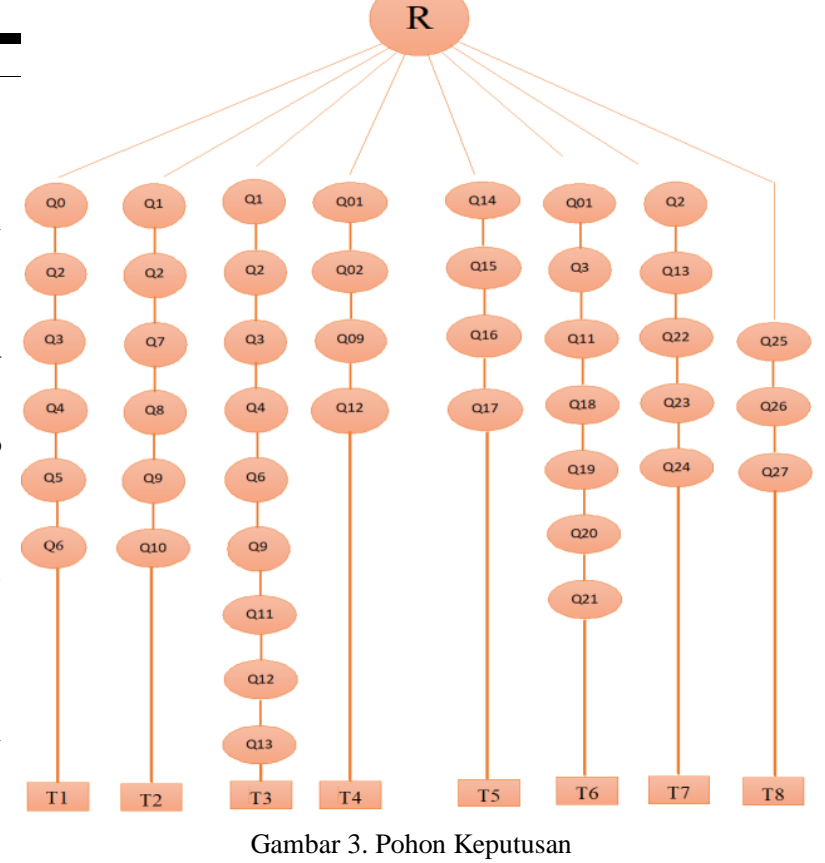

\subsubsection{Nilai Bobot Dari Gejala Penyakit}

Nilai bobot gejala yang didapat dari wawancara dari pakar, yang dapat dilihat seperti pada Tabel 7.

Tabel 5. Nilai Bobot gejala

\begin{tabular}{cc}
\hline Kode Gejala $(\mathrm{Q})$ & Nilai Bobot Gejala \\
\hline Q1 & 5 \\
Q2 & 10 \\
Q3 & 10 \\
Q4 & 10 \\
Q5 & 15 \\
Q6 & 15 \\
Q7 & 15 \\
Q8 & 10 \\
Q9 & 5 \\
Q10 & 15 \\
Q11 & 15 \\
Q12 & 20 \\
Q13 & 20 \\
Q14 & 20 \\
Q15 & 15 \\
Q16 & 20 \\
Q17 & 25 \\
Q18 & 20 \\
Q19 & 15 \\
Q20 & 5 \\
Q21 & 20 \\
Q22 & 15 \\
Q23 & 20 \\
Q24 & 15 \\
Q25 & 20 \\
Q26 & 20 \\
Q27 & 25 \\
\hline
\end{tabular}

\subsubsection{Membuat Pohon Keputusan}

\subsection{Pengujian Data}

Untuk mengambarkan lebih jelas alur penelitian dengan menggunakan metode Forward Chaining. Berdasarkan data yang telah disusun maka diberikan suatu pohon Berdasarkan proses diagnosa yang dilakukan oleh keputusan untuk mempermudah peneliti dalam pasien 1, melalui gejala penyakit yang dirasakan yaitu Menyusun penelitiannya. Pohon keputusan dapat Q1, Q3, Q11, Q18, Q19, Q20, Q21, maka dapat dilihat pada gambar 3 .

disimpulkan hasil konsultasinya adalah Periodentitis.

Dengan tingkat keparahan berikut:

Jurnal Sistim Informasi dan Teknologi Vol. 3 No. 2 (2021) 41-47 
Ilham Roni Yansyah, Sumijan.

$$
\begin{aligned}
\text { Tingkat Keparahan } & =\text { Total Nilai bobot } \\
& =\mathrm{Q} 1+\mathrm{Q} 3+\mathrm{Q} 11+\mathrm{Q} 18 \\
& +\mathrm{Q} 19+\mathrm{Q} 20+\mathrm{Q} 21 \\
& =5+10+15+20+15+5 \\
& =70 \%
\end{aligned}
$$

Jadi tingkat keparahan penyakit Gigi dan mulut yang di derita pasien $70 \%$ dengan diagnose penyakit yaitu Periodentitis.

b. Pasien 2

Berdasarkan proses diagnosa yang dilakukan oleh pasien 2, melalui gejala penyakit yang dirasakan yaitu Q1, Q2, Q9, Q12, maka dapat disimpulkan hasil konsultasinya adalah Pulpitis. Dengan tingkat keparahan berikut:

Tingkat Keparahan = Total Nilai bobot

$$
\begin{aligned}
& =\mathrm{Q} 1+\mathrm{Q} 2+\mathrm{Q} 9+\mathrm{Q} 12 \\
& =5+10+5+20+15 \\
& =55 \%
\end{aligned}
$$

Jadi tingkat keparahan penyakit Gigi dan mulut yang di derita pasien $55 \%$ dengan diagnosa penyakit yaitu Pulpitis.

\section{c. Pasien 3}

Berdasarkan proses diagnosa yang dilakukan oleh pasien 3, melalui gejala penyakit yang dirasakan yaitu Q1，Q2，Q9， Q12， maka dapat disimpulkan hasil konsultasinya adalah Impaksi Gigi. Dengan tingkat keparahan berikut:

Tingkat Keparahan

$$
\begin{aligned}
& =\text { Total Nilai bobot } \\
& =\mathrm{Q} 2+\mathrm{Q} 13+\mathrm{Q} 22+\mathrm{Q} 23 \\
& +\mathrm{Q} 24 \\
& =10+20+15+2 \\
& =40 \%
\end{aligned}
$$

Jadi tingkat keparahan penyakit Gigi dan mulut yang di derita pasien $40 \%$ dengan diagnosa penyakit yaitu Impaksi Gigi.

\section{d. Pasien 4}

Berdasarkan proses diagnosa yang dilakukan oleh pasien 4, melalui gejala penyakit yang dirasakan yaitu Q1, Q2, Q3, Q4, Q5, Q6 maka dapat disimpulkan hasil konsultasinya adalah Gingivitis. Dengan tingkat keparahan berikut:

$$
\begin{aligned}
\text { Tingkat Keparahan } & =\text { Total Nilai bobot } \\
& =\mathrm{Q} 1+\mathrm{Q} 2+\mathrm{Q} 3+\mathrm{Q} 4+\mathrm{Q} 5+\mathrm{Q} 6 \\
& =5+10+10+10+15+15 \\
& =65 \%
\end{aligned}
$$

Jadi tingkat keparahan penyakit Gigi dan mulut yang di derita pasien $65 \%$ dengan diagnosa penyakit yaitu Gingivitis.

\subsection{Hasil}

Berdasarkan hasil perhitungan dengan menggunakan metode Forward Chaining, dan dengan perhitungan tingkat keparahan penyakit gigi dan mulut maka diperoleh hasil ada pada Table 6 .

Tabel 6. Hasil Pengujian

\begin{tabular}{llc} 
Pasien & Penyakit & Tingkat Keparahan \\
\hline Pasien 1 & Periodentitis & $70 \%$ \\
Pasien 2 & Pulpitis & $55 \%$ \\
Pasien 3 & Impaksi Gigi & $40 \%$ \\
Pasien 4 & Gingivitis & $65 \%$ \\
\hline
\end{tabular}

Hasil dari Sistem Pakar dapat dilihat dengan menggunakan software yang telah dibangun menggunakan Framework Codeigniter. Berikut tampilan sistem pakar mengukur tingkat keparahan penyakit gigi dan mulut.

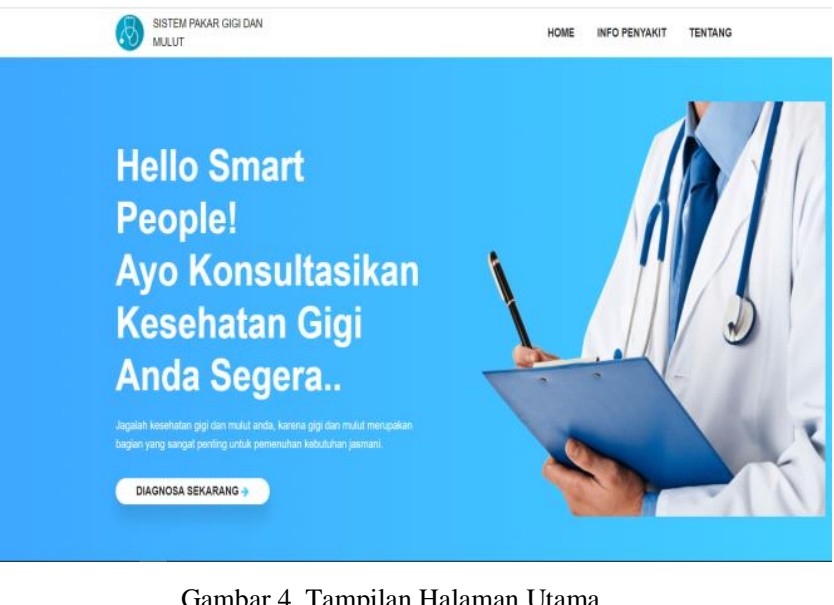

Gambar 4 menunjukkan halaman utama untuk menampilkan semua menu yang bisa diakses oleh user umum.
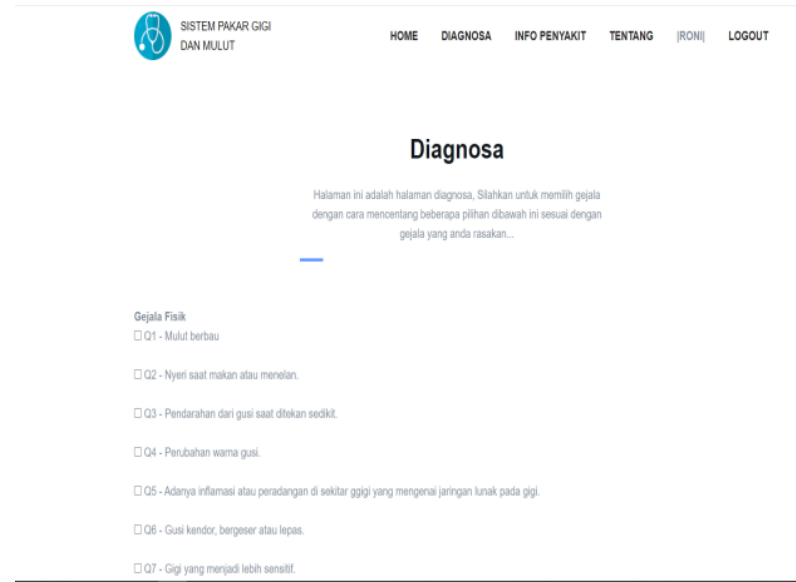

Gambar 5. Tampilan Halaman Konsultasi

Pada halaman ini menampilkan proses konsultasi pasien dengan Sistemyang dibuat, yaitu pasien

Jurnal Sistim Informasi dan Teknologi Vol. 3 No. 2 (2021) 41-47 
menjawab pertanyaan dengan mencentang jika jawabannya iya dan kosong jika tidak, jawaban berdasarkan berdasarkan gejala yang dirasakan oleh pasien. Setelah pasien melakukan konsultasi dengan Sistem, maka akan ditampilkan hasil konsultasi pasien seperti pada Gambar 6 .
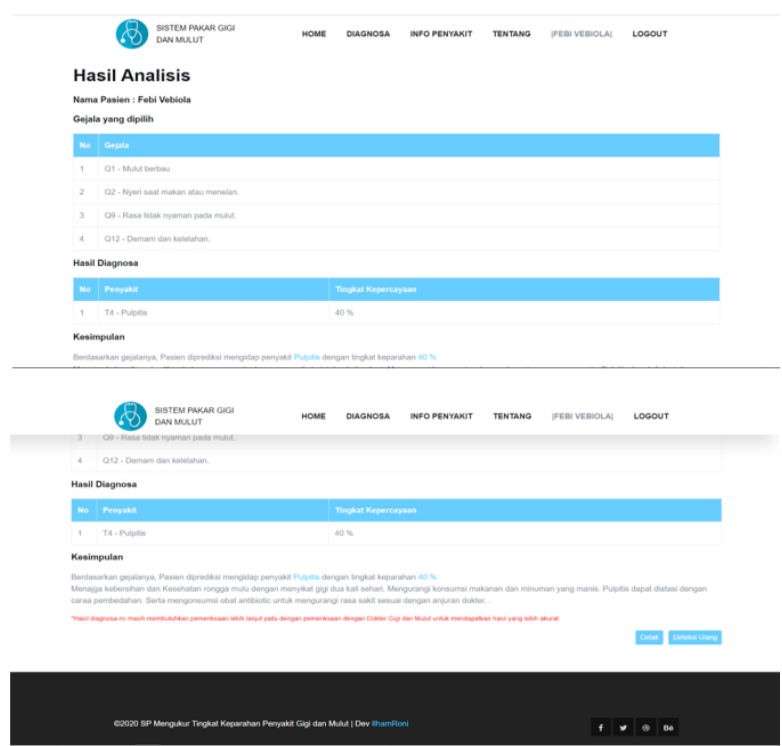

Gambar 6. Tampilan Hasil Konsultasi

Selanjutnya dilakukan pengujian terhadap 10 data pasien dengan membandingkan dengan hasil dari pakar untuk melihat tingkat akurasi hasil. Untuk menghitung nilai probabilitas hingga mendapatkan tingkat akurasi Sistem Pakar dalam mengukur tingkat keparahan penyakit Gigi dan Mulut dengan metode Forward Chaining, maka dilakukan dengan peritungan menggunakan rumus probalilitas sebagai berikut:

Rumus Probabilitas :

$P_{(E)}=\frac{X}{N} \times 100 \%$

Dimana:

- P:Probalilita;

- E : Event;

- $\mathrm{X}$ :Jumlah kejadian yang terjadi;

- $\mathrm{N}$ :Jumlah seluruh kejadian.

Seperti yang telah dijelakan bahwa penilaian keakuratan sistem terdiri dari 2 level, yaitu level 0 dan level 1. Level 0 diberikan jika hasil diagnosa sistem tidak sama dengan hasil diagnosa pakar dan level 1 diberikan jika diagnosa sistem sama dengan hasil diagnosa pakar. Maka pada kasus penelitian ini dapat dihitung probabilitasnya diperoleh hasil sebagai berikut:

$$
\begin{aligned}
\text { (Akurat) } & =\frac{X}{N} \times 100 \% \\
& =9 / 10 \times 100 \% \\
& =90 \%
\end{aligned}
$$

(Tidak akurat) $=\mathrm{x} 100 \%$

$$
=1 / 10 \times 100 \%
$$$$
=90 \%
$$

Dari hasil probabilitas maka nilai akurasi sistem dengan hasil keputusan pakar mencapai 90\% dalam analisis penyakit Gigi dan Mulut dengan metode Forward Chainging. Hasil terhadap penelitian ini adalah analisis penyakait Gigi dan Mulut, solusi dan pencegahan penyakit Gigi dan Mulut. Setelah dilakukan pengujian dan perhitungan tingkat akurasi sistem, maka didapatkan tingkat akurasi yang baik dari hasil perhitungan sistem dengan keputusan pakar sebesar 90\% dari 10 data pengujian. Berdasarkan tingkat akurasi dari hasil identifikasi terhadap sistem, maka penelitian ini sangat tepat dalam analisis penyakit Gigi dan Mulut.

\section{Kesimpulan}

Penelitian ini dapat mengidentifikasi penyakit gigi dan mulut serta dapat menentukan tingkat keparahan penyakit gigi dan mulut yang diderita pasien. Sehingga penelitian ini dapat menjadi rujukan dalam mengidentifikasi penyakit gigi dan mulut serta memberikan pengetahuan kepada pasien tentang perawatan kesihatan gigi dan mulut.

\section{Daftar Rujukan}

[1] Rifqo, M. H., Prabowo, D. A., \& Haura, M. (2019). Perbandingan Metode Certainty Factor dan Dempster-Shafer Pada Sistem Pakar Diagnosa Penyakit Gigi dan Mulut. Jurnal Informatika Upgris, 5(2), 150-156. DOI: http://dx.doi.org/10.26877/jiu.v5i2.4225

[2] Syawitri, A., Defit, S., \& Nurcahyo, G. W. (2018). Diagnosis Penyakit Gigi dan Mulut dengan Metode Forward Chaining. Jurnal Sains, Teknologi, \& Industri, 16(1), 24-29. DOI: https://doi.org/10.24014/sitekin.v16i1.6733

[3] Pranata, F. S., Na'am, J., \& Sumijan. (2019). Sistem Pakar Diagnosis Penyakit Jamur pada Manusia Menggunakan Input Suara Berbasis Android. Jurnal RESTI (Rekayasa Sistem dan Teknologi Informasi), 3(3), 435-442. DOI: https://doi.org/10.29207/resti.v3i3.1187 .

[4] Husin, A., Usman, U., \& Faren, M. P. (2019). Sistem Pakar Pendeteksi Penyakit Berdasarkan Keluhan Buang Air Kecil Menggunakan Metode Forward Chaining. Jurnal Ipteks Terapan, 12(4), 277-285.

[5] Rahman, F., \& Ratna, S. (2018). Perancangan E-learning Berbasis Web Menggunakan Framework Codeigniter. Technologia: Jurnal Ilmiah, 9(2), 95. DOI: http://doi.org/10.31602/tji.v9i2.1370 .

[6] Sari, M. P., \& Realize, R. (2019). Sistem Pakar Mendiagnosa Penyakit Osteoporosis Pada Lansia Menggunakan Metode Forward Chaining Berbasis Web. Jurnal Ilmiah Informatika, 7(1). DOI: https://doi.org/10.33884/jif.v7i01.906

[7] Harjanto, A., Karnila, S., \& Nugraha, F. (2018). Rancang Bangun Aplikasi Sistem Pakar Untuk Konsultasi Perilaku Siswa di Sekolah Menggunakan Metode Forward Chaining. Simetris: Jurnal Teknik Mesin, Elektro dan Ilmu Komputer, 9(2), 817-824. DOI: https://doi.org/10.24176/simet.v9i2.2367 .

[8] Afandi, H., \& Sulistyo, D. A. (2019). Sistem Pakar Untuk Diagnosa Hama dan Penyakit Pada Bunga Krisan Menggunakan Forward Chaining. Jurnal Ilmiah Teknologi Informasi dan Ilmu

Jurnal Sistim Informasi dan Teknologi Vol. 3 No. 2 (2021) 41-47 
Ilham Roni Yansyah, Sumijan.
Komputer
Asia,
$13(2)$
101-114.
DOI:

https://doi.org/10.32815/jitika.v13i2.409

[9] Tobing, D. M. L., Pawan, E., Neno, F. E., \& Kusrini, K. (2019). Sistem Pakar Mendeteksi Penyakit Pada Tanaman Padi Menggunakan Metode Forward Chaining. Sisfotenika, 9(2), 126137. DOI: http://dx.doi.org/10.30700/jst.v9i2.440

[10]Mawaddah, U., \& Fauzi, M. (2018). Sistem Pendukung Keputusan Untuk Menentukan Dosis Obat Pada Anak Menggunakan Metode Forward Chaining (Studi Kasus Di Klinik Dokter Umum Karanggayam-Srengat). Antivirus: Jurnal Ilmiah Teknik Informatika, 12(1). DOI: https://doi.org/10.35457/antivirus.v12i1.440 . 